\title{
O RIO CROA: RESULTADO DE MUITAS VOZES UM LUGAR NARRADO NAS PERSPECTIVAS DO ECOTURISMO
}

Pabla Alexandre Pinheiro da Silva ${ }^{1}$

\section{RESUMO}

O rio Croa está localizado no munícipio de Cruzeiro do Sul, a segunda maior cidade do Acre. A riqueza de sua flora e a diversidade de sua fauna têm chamado atenção de muitos turistas do Brasil e fora dele, que buscam nesse lugar encontrar paz e espiritualidade. Este artigo se propõe a refletir sobre as notícias veiculadas no Estado do Acre através de sites que narram/ representam o Rio Croa como um paraíso, lugar de encanto, de um povo gentil e com um grande potencial turístico. Ao analisar esse discurso por meio do pensamento de Bakhtin pode-se compreender como foram tecidas essas narrativas. Como o discurso foi construído a partir de nuances de uma realidade que já foi dada, fruto de uma memória discursiva e como dialogicamente, novos elementos foram sendo inseridos ao enunciado, mediante a perspectiva do turismo na região. A comunidade que vive às margens desse rio está dialogicamente inserindo novos significados, novas leituras de um lugar, revelando que a imagem edênica, já presente em algumas narrativas do "Novo Mundo" está viva e ainda povoa o imaginário da atualidade. É o antigo discurso, tecendo um novo.

\section{PALAVRAS-CHAVE}

Rio Croa. Paraíso. Discurso. Turismo. Amazônia.

\section{INTRODUÇÃO}

Como analisar um discurso sobre determinado lugar na Amazônia, sem levar em consideração o que já foi dito desse lugar? Como tentar resistir a um fluxo tão grande de representações que assim como um rio, corre sempre numa mesma direção? Como deixar de ouvir as vozes que gritam e a memória que não deixa esquecer que o que foi dito, já criou raízes e está ali, reinando como uma imperiosa samaúma, tornando impossível não percebê-la em meio à floresta?

Como se deixa calar as inúmeras obras que constroem esse lugar? De Ugarte (2009), Euclides da Cunha (2006), Leandro Tocantins (2000) e tantos outros, a Amazônia já foi pintada em tela, com tintas que muitas vezes não refletem sua realidade. Essas obras já analisaram seus rios, comparando-os, descrevendo-os. Algumas já erroneamente caluniaram seu clima, seus animais e seus habitantes.

O discurso que narra o rio Croa não poderia tomar um caminho diferente. Localizado na região amazônica, esse rio tem sido palco de muitas representações. Distante 60 quilômetros da cidade de Cruzeiro do Sul pela BR 364, esse rio tem chamado atenção pelas suas características vistas como peculiares: as águas escuras que compõem uma bela paisagem, a diversidade da fauna e da flora, os gentis ribeirinhos e, as comunidades "daimistas" e "ayahuasqueira". Todos esses elementos tornam o Croa, na visão dos moradores locais e do Governo do Acre, um lugar ideal para a prática do turismo.

Quem visita o Rio Croa pela primeira vez, não possui geralmente a habilidade de fugir desse contexto discursivo em que esse rio e o lugar já estão inseridos. Impossível não perceber suas águas escuras repletas de vitórias régias que parecem dar boas-vindas aos visitantes. No balançar tranquilo da canoa, e tendo como trilha sonora o canto dos pássaros e do motor da pequena embarcação, as primeiras casas da comunidade se revelam aos visitantes. Muito pouco se falam delas, o personagem principal é o Rio. É ele quem comanda a vida, como diria Leandro Tocantins.

Nas muitas narrativas sobre a Amazônia, predomina o elemento humano como apenas um ator coadjuvante. Neste caso o ator principal é sempre o rio, ele reina soberano. É ele que margeia as casas, as florestas e os sujeitos que nele vivem. É o rio que impõe sua marca. É o rio que controla sua marcha. Leandro Tocantins (2000) nos revela essa dinâmica quando fala que: "As comunidades, as barracas, os barracões se desenvolvem à beira dos rios, junto aos barrancos, equilibrados nos esteios, prontos

1 Mestre em Letras pelo Programa de Pós-Graduação em Letras: Linguagem e Identidade da Universidade Federal do Acre - UFAC e servidora do Instituto Federal de Educação do Acre - IFAC . 
para locomoverem-se à ré se as terras caídas ameaçarem as palafitas, mas sempre junto da água, na atração máxima do caudal que é a vereda das energias vitais" (TOCANTINS, 2000, p. 233).

Ao percorrer as curvas do Croa, como é carinhosamente chamado por seus moradores, um cenário se descortina e se revela aos olhos que não estão acostumados com a geografia desse lugar. São casas de madeiras com palhas no telhado que te espreitam nas margens. Aqui e acolá você vê um tucano, uma jiboia, um peixe que aparece para comer algo que você deixou cair na água. As grandes árvores caídas beijam profundamente o seu leito, seus troncos tombados revelam que foram majestosas e que algo sobrenatural as derrubou. Um pensamento então surge: uma força capaz de pôr abaixo uma árvore tão frondosa é capaz de punir aos incautos que teimam em enfrentar a sua fúria.

Bem mais a frente, meninos se banham nas águas, enquanto as mães estão lavando as roupas em um trapiche. Há galinhas ciscando e canoas trafegando a todo o momento. O Rio Croa não para. O turista que o visita fica fascinado com o dinamismo desse espaço geográfico tão exaustivamente narrado pelos autores que tentaram compreender a Amazônia.

Não é surpresa que o rio amazônico seduz, encanta e assusta. Pois o espetáculo da natureza se abre em múltiplas formas. É no gorjear de um pássaro, é no grito alegre das crianças, é o balanço das árvores, é o deslumbramento com o tudo que se revela aos olhos. Euclides da Cunha (2006) deve ter sentido o mesmo espanto ao se deparar com a floresta amazônica. Tudo aqui se mostra grandioso, majestoso. A samaúma gigantesca atrai, não só por sua presença imponente, mas também por sua ligação espiritual. Os praticantes do Daime na região usam-na em seus ritos, pois acreditam haver nela uma elevação espiritual. Há toda uma construção de significados nesse local que vai desde a prática do Daime/Ayahuasca até a preservação da floresta.

Quando se fala ou se escreve sobre o Croa inúmeras palavras surgem para compor essa narrativa. O discurso já está pré-formado, o gênero que utilizamos vai sendo tecido a partir de diferentes falas, recebidas em diferentes contextos. Essa visão romanceada faz parte de uma "memória discursiva". São "vozes" que sussurram e determinam o cotidiano amazônico. São palavras incorporadas ao discurso através da interação social. O que você fala, escreve ou pensa, são resultados dessas "vozes". Bakhtin diz que "essas palavras dos outros trazem consigo a sua expressão, o seu tom valorativo que assimilamos, reelaboramos e reacentuamos” (BAKHTIN, 2003, p. 295)

Não há maneira de se ver/perceber o rio Croa de outra forma. O olhar já foi direcionado/ensinado/doutrinado. O relato já está impregnado de significados. São símbolos que perpassam o tempo e o lugar. A figura do rio, da floresta ou dos sujeitos que vivem nessa localidade já foram narradas, obedecendo a um discurso determinado tanto social como historicamente.

O rio Croa ou qualquer outro rio será sempre descrito seguindo a dinâmica amazônica da representação geográfica. O homem é apenas um inquilino indesejável. Que se adapta e persiste, aquele que vence as agruras de um lugar inóspito. Sobrevivendo através da "seleção natural invertida" tão presente nos escritos de Euclides.

No contexto amazônico as palavras como paraíso, inferno, isolamento, sertão, deserto, entre outras, estão presentes no imaginário dos sujeitos dessa região. Foram incorporadas numa conversa na feira, em casa ou numa roda de amigos. Já foram lidas num livro, contadas num "causo", numa notícia de jornal, na música regional, site ou numa minissérie. Elas pertencem a esse lugar. São resultados de uma consciência/memória coletiva. Foram assimiladas, disseminadas, construídas e ressignificadas. Elas fazem parte dessa paisagem. Elas constroem sentidos e significados.

É com base nessa concepção de que o gênero discursivo presente nos textos sobre a Amazônia obedece a uma forma-padrão, determinada por fatores históricos, culturais e sociais, que no 
presente artigo proponho a analisar algumas reportagens sobre o Rio Croa veiculadas no Estado do Acre, procurando os elementos que possam sugerir, apontar ou reforçar que esses enunciados já foram proferidos em outras épocas, em outras situações e que foram usados para formular um novo discurso, numa tentativa de criar uma determinada personalidade do Rio Croa. É um antigo discurso, inserido num novo contexto, criando novos enunciados, novos olhares e novos signos.

Nesse sentido ao analisarmos esses enunciados tendo como referencial teórico Mikhail Bakhtin, pretendemos expor que tal discurso já foi moldado por um gênero hegemônico que direciona a visão que se deve ter de um determinado lugar na Amazônia. Que a forma de falar ou escrever sobre o Rio Croa é tão "natural", que não nos damos conta disso. Tal processo acontece de acordo com Bakhtin, "quase da mesma forma que nos é dada a língua materna, a qual dominamos livremente até começarmos o estudo da gramática” (BAKHTIN, 2003, p. 282).

Entretanto, esse discurso que descreve o Croa está inserido em uma nova ordem, buscando retratar esse lugar, determinando características marcantes e elementos interessantes que possam provocar curiosidade, imaginação, vontade de conhecer e averiguar se realmente é verdade tudo o que dizem desse rio de águas escuras.

Ao iniciar a análise das reportagens, uma temática central é encontrada nas quatro matérias que serão abordadas nesse artigo, revelando uma semelhança assustadora e apresentando características solidificadas há muito tempo atrás, embora um novo discurso esteja presente em todas elas, o discurso do ecoturismo. Todas possuem uma perturbadora intenção de direcionar/provocar o olhar do leitor. Ao ler "No Coração do Croa" e "Rio Croa: Água Escura que espelha a Beleza do Acre”, publicadas pela Agência de Notícias do Acre- ANA (www.agencia.ac.gov.br), "Programa Luz para todos chega ao Rio Croa", publicada em 07 de dezembro de 2011 pelo site Juruá online (www.juruaonline.com.br), "Fenômeno natural deixa rio com ares de lago paradisíaco no Acre", publicada pelo portal G1 (http:// g1.globo.com), percebemos o sólido discurso de que o paraíso é ali e que todos devem conhecer esse lugar tão lindo.

Essa temática do paraíso que faz parte das narrativas sobre o Croa tem um fim específico, reflete uma necessidade premente de explorar as potencialidades turísticas do local. As matérias que serão analisadas revelam o interesse do Governo do Estado e também da comunidade local em tornar o Rio Croa um espaço de ecoturismo. O elemento econômico se faz presente em todas elas. É a política de sustentabilidade disseminada pelo governo encontrando no discurso do paraíso, um lugar fértil para a exploração das belas paisagens do Croa.

Bem sabemos que as publicações jornalísticas são feitas para um devido propósito, bem como todo e qualquer ato enunciativo. Tendo por base essas considerações, pautamos a discussão dessas matérias, mostrando que a visão que se tinha da Amazônia e que está contida nessas reportagens servem para um propósito específico, o de atrair turista para a região. É o conhecido discurso do Éden, compondo o novo discurso do ecoturismo. É a visão do paraíso com o intuito de atrair turistas. É a construção de uma paisagem publicitária, que visa extrair e revelar a alma do lugar.

As quatro narrativas publicadas sugerem que o Croa é um lugar lindo, tendo um grande potencial para o turismo contemplativo. Investir em uma estrutura que mantenha a preservação desse espaço e que possibilite a criação de cabanas para alojar aos turistas é uma proposta defendida pelo governo e amplamente divulgada entre a comunidade. Discurso esse que fazia parte do programa do "Governo da Floresta”" (slogan da administração do governador Jorge Viana, 1999/2007) e que é visivelmente percebido em todas as reportagens. A presença das instituições estatais está imbricada nessas narrativas compondo um contexto histórico-social e possibilitando que a política de sustentabilidade ganhe força. 
Com base nisso, iniciamos a análise da primeira matéria, escrita pela jornalista Tatiana Campos em 16/01/2012 com o título "No coração do Croa". Como sugere a jornalista "prepare o seu coração para grandes emoções. Navegar pelo Croa, um rio lindo, de águas escuras e matas fechadas, pode reservar surpresas" (CAMPOS, 2012).

Em seu texto encontramos a visão do exótico, do deslumbramento com o capricho da natureza, do espanto ao descobrir uma cobra bem próxima da equipe de reportagem, de um lugar abençoado e místico, mantendo assim a ideia que se tem da Amazônia, presente nos textos de Euclides da Cunha (2006), Leandro Tocantins (2000) e dos viajante ibéricos analisados por Ugarte (2009). O Croa se revela como um lugar de paz, de plantas aquáticas e tucanos, um lugar de natureza bruta. A presença do homem parece não interferir na paisagem local. Ele é um coadjuvante, aquele que fica à espreita, aquele que aguarda pacientemente receber da terra o que precisa. O texto da autora busca provocar uma reação nos leitores, procura iniciar um diálogo. Conversa com o discurso idílico já conhecido na região e apresenta um olhar mais na frente, dialogando com as potencialidades turísticas do Croa. Seu texto não é sutil.

Também não há sutileza nas imagens que foram feitas por Sérgio Vale, fotógrafo responsável pela maioria das imagens utilizadas pelo governo. Elas retratam um menino se divertindo num banho de rio, uma vitória régia e a mencionada cobra descansando tranquilamente na copa de uma árvore. A visita em fins de 2011 do governador do Acre Tião Viana e a presença da primeira-dama representam uma confirmação de que o Croa é especial. É reforçado discurso do Estado do Acre defendendo as belezas da floresta e garantindo a subsistência dos ribeirinhos que vivem nessa "natureza bruta". Pois os investimentos em infraestrutura e no turismo serviriam para proporcionar meios de sobrevivência a essas famílias.

Ao analisar a construção dessa narrativa, com base nos estudos de Bakhtin, podemos refletir como foi construída essa reportagem. Quais elementos compõem esse discurso. O contexto histórico-social foi criado para tornar o discurso mais real. Essa concepção do paraíso torna possível as oportunidades de transformar o Croa num lugar ideal para passeios, trilhas, banho de rio, enfim, contemplar e aproveitar as belezas do lugar. Segundo Bakhtin, todo enunciado tem um propósito. Ele busca convencer, influenciar. Ele não é passivo. Há uma interação entre os sujeitos envolvidos. A pessoa que escreve tenta direcionar o olhar de quem está lendo a mensagem.

Nesse processo dialógico, elementos estão sendo assimilados e reelaborados. O tema da matéria deixa claro que o objetivo seria as possibilidades de se investir em turismo na região. Tanto a forma como foi escrito o enunciado, como as imagens escolhidas, refletem o objetivo de explorar de forma sustentável as atrações turísticas do Rio Croa. E servem também para reforçar a política do governo em preservar a região. Em permitir que a comunidade se sustente e preserve o local, pensamento presente no programa de sustentabilidade do governo e bem claro nas palavras da primeira-dama, Marlúcia Cândido quando fala:

A ideia é que o turismo aqui não seja de aventura, mas contemplativo. E que sejam construídas dez cabanas, para que a demanda seja agendada, com controle, e as pessoas possam vir, estacionar o carro num deck ao lado da ponte, almoçar, contemplar a natureza, observar os pássaros. É importante que a comunidade tenha como se sustentar para continuar preservando a floresta (CAMPOS, 2012).

O contexto paraíso e turismo também estão claramente abordados na próxima reportagem, que tem como título "Programa Luz para todos chega ao Rio Croa", publicado no site Juruá online, em 07 de setembro de 2011. Nela é narrado como foi à chegada da luz na comunidade. Fogos e festas receberam com alegria o governador Tião Viana e sua equipe. Tudo isso para comemorar os 10 quilômetros de rede que cortam a floresta e levam energia às casas dos ribeirinhos.

Para que tudo isso fosse possível, estradas foram abertas no meio da floresta para a ins- 
talação da rede elétrica, entretanto, essas estradas serão desativadas para garantir a preservação do Croa, como afirma a referida matéria. Apesar do tamanho do enunciado, as tessituras presentes em seu texto revelam a mesma intenção do texto da Tatiana Campos. Os elementos que fizeram parte de sua narrativa estão visivelmente expostos nesse discurso. A única imagem que ilustra a matéria é de uma canoa que desliza pelas águas tendo um passageiro ilustre (o governador), reforçando a presença do olhar atento do governo a essas paragens.

Tal imagem torna possível perceber que a concepção do Croa como o paraíso turístico e a intervenção governamental estão entrelaçadas. A luz elétrica seria muito benvinda nos planos de tornar esse lugar um atrativo aos visitantes. As palavras do governador Tião Viana resumem muito bem a objetivo dessa ação, quando diz que "Isso aqui talvez seja o lugar mais bonito do mundo, só quem vem por esse rio de canoa sabe o significado. O governo da presidente Dilma está trazendo o projeto "Luz para Todos”. É a presença do governo nessa comunidade, num ambiente de ecoturismo” (Juruá online, 2011). Ou seja, numa outra leitura, a Amazônia continua sendo vista com seus mistérios e belezas e agora, todos são convidados a visitarem o Croa e contemplar de perto esse Éden.

Seguindo essa mesma dinâmica discursiva a reportagem, "Rio Croa: água escura que espelha a beleza do Acre", sem autoria identificada e publicada também pela Agência de Notícia do Acre - ANA (2015), mantém os mesmos elementos: paraíso, turismo e presença do governo do Estado. As palavras que situaram as matérias de Tatiana Campos e a do site Juruá online também são encontradas nessa reportagem. É a visão edênica surgida nas narrativas do século XVI e que ainda hoje se mantém viva em qualquer discurso que representa o Croa.

O lugar de paz, o encanto, a beleza, a espiritualidade, o rio e o paraíso se repetem nas linhas que se seguem no texto. Entretanto, outros signos são apresentados nesse discurso. O homem gentil, a vida cabocla, o Santo Daime e as vozes dos ribeirinhos determinam o enunciado e apresentam novos fios para as tessituras identitárias desse espaço.

As imagens utilizadas para compor o texto retratam um pouco o dia a dia das mais de 50 famílias que residem no Croa. O cotidiano se revela através de pequenos fragmentos de imagem que sugerem como é a interação entre homem e o espaço geográfico amazônico.

A primeira fotografia reflete essa interação. Uma pequena canoa tenta passar entre as vitórias régias. Essa planta é sem dúvida uma "garota" propaganda do Rio Croa. Ela aparece constantemente nas conversas e nas fotos dos visitantes. Ela reina soberana em suas águas. Muitas vezes atrapalha o tráfego no rio, obrigando a comunidade a limpar o leito, retirando-as, tentando manter o vai e vem das inúmeras canoas que, diariamente, percorrem o rio.

A utilização dessas imagens serve como provocadora de um discurso, tornando a leitura mais apelativa. Bakhtin comenta que quando olhamos para uma imagem e dizemos que ela é linda, estamos carregando a palavra de sentido. A imagem provoca, convida a outro enunciado. A floresta ao fundo, a vegetação aquática e o homem são um espetáculo aos olhos de quem vê. Através dessas imagens nos damos conta que o elemento humano está inserido nesse contexto histórico discursivo. Ele é um discurso, uma construção narrativa. E esse mesmo homem vai reproduzir o que ouviu sobre si mesmo e sobre o lugar, e inserir outros elementos em sua fala. São os sons de muitas vozes compondo um único enredo. O gênero em uso na reportagem está presente na fala do caboclo amazônico. Ele não tem como fugir a esse contexto, já que o que ele diz advém de discursos proferidos no exato momento de sua interação social.

O dito já foi assimilado e serve na formulação do que vai ser falado. É nessa interatividade de sujeitos falantes que surge uma visão coletiva. O ribeirinho aprendeu a conviver/sobreviver na 
floresta. Aprende a respeitá-la. O significado de pertencimento são fios que ligam o homem a esse espaço geográfico. Suas palavras são frutos de uma memória oral, produtos de uma construção coletiva que narra o Croa. Suas falas demostram o amor e a preocupação em manter seguro o seu lar. Essa preocupação resultou na regularização das terras pelo Instituto de Terras do Acre - Iteracre (ANA, 2015). A luta incessante da comunidade local em transformar o Croa numa reserva de proteção ambiental proporcionou a regularização da propriedade rural. Isso significa poder contar com políticas públicas que garantam a saúde, a educação e financiamentos para a agricultura e pequenos negócios.

O gentil "caboclo amazônico" preocupa-se em manter seu lar. Em manter a floresta e os rios intactos, pois ele os reverencia. Nessa relação de cumplicidade o olhar desse habitante sobre a sua casa, sobre o seu local de morada, reflete bem essa condição de pertencimento. O Croa consome esse caboclo, influencia seu estilo de vida, seu comportamento. É o rio que permite sua permanência e como um bom inquilino, preocupa-se em manter o seu lar.

Esse homem "gentil" te convida a um novo diálogo, pois é comum ouvir de algumas pessoas sobre a humildade e a simpatia das pessoas que vivem nas margens dos rios. Em quase todos os comentários ouvimos sobre a gentileza, sobre os costumes de se tratar bem aos visitantes e muitas outras palavras que expressam a bondade desses ribeirinhos. Nessa reportagem temos um vislumbre dessas expressões. São pessoas que agem com o coração e que são levados pelo sentimento. É comum ouvir apelidos carinhosos, demonstrando a estreiteza das relações.

É o amor pelo lugar, pelos amigos, pelos vizinhos. É o pernoitar na casa, é o vizinhar depois de uma boa pesca, enfim são práticas diárias que revelam sua cordialidade. Esse homem "cordial" é o que te convida para tomar um café e te oferece um cigarro de porronca. Demonstrar intimidade e proximidade já faz parte das "raízes” brasileiras e essa prática pode ser encontrada nas pessoas residentes no Croa. Elas te ensinam a andar nas trilhas, te avisam sobre o perigo da cobra e do caboclinho da mata.

Esse homem "cordial" te convida a pescar no rio repleto de peixes, isso só acontece se ele gostar de você, pois apenas os convidados têm a permissão de pescar nas águas escuras do Croa. Entretanto, não se iluda com a cordialidade do ribeirinho, pois ele mostra-se corajoso e forte quando se sente ameaçado, mostrando o amor e o respeito pela floresta que o abrigou.

Desde o início das primeiras visitas a Amazônia se buscou determinar o tipo dos habitantes desse lugar. Assim como o Croa, seus habitantes também fazem parte de um gênero narrativo. São índios, selvagens, silvícolas, brabos, arigós, mansos, nordestinos, gentis e caboclos. O termo "caboclo" encontrado nesse texto é um desses tipos que já foram representados. Ele é comumente usado para descrever esse homem que vive na Região Norte. Sua construção histórica está nitidamente ligada à formação da sociedade amazônica.

Por ser um termo abstrato, uma representação, a referência ao "caboclo" pode está aberta a diversas análises e leituras. Por se tratar de um conceito, ele pode ser utilizado em diferentes contextos carregados de inúmeros significados. Pode estar se referindo ao homem que vive na floresta. Ele pode ser usado, entre amigos para nomear carinhosamente uma pessoa. Num contexto étnico pode se referir ao filho do branco com o índio. Em termos geográficos, pode designar as pessoas que vivem na Amazônia, ou entre desafetos, uma maneira de provocar o outro, de chamá-lo de analfabeto, de rude, numa tentativa de inferiorizá-lo.

Essa representação do caboclo e de sua vida encontrada nessa reportagem, não é algo recente. Ela já faz parte de uma narrativa encontrada na Revista Brasileira de Geografia em 1948. No capítulo "Tipos e Aspectos do Brasil”, um dos subtítulos fala sobre o "Caboclo Amazônico". Nele, José Veríssimo da Costa Pereira diz que o Censo Demográfico de 1940 afirma que "da população da Região 
Norte ou Amazônica, é constituído de tipos mestiços (caboclo, moreno, mulato, etc.), oficialmente consignados sob a singela designação de pardos” (PEREIRA, 1948, p. 129).

Nas linhas que se seguem José Veríssimo da Costa Pereira descreve com detalhes as características físicas e culturais dos caboclos amazônicos. Segundo ele há uma predominância dos traços indígenas, seja na cor da pele, na textura do cabelo e até mesmo no seu modo de viver. Ele diz que

Onde quer que atue, e seja qual fôr a atividade a que se dedique, o caboclo amazônico traduz sempre a influência atávica na região. Antes de tudo é um nômade. Preferencialmente é um coletor, um pescador ou um caçador. Uma vez ou outra, dedica-se à minguada cultura de subsistência, aproveitando ora uma nesga de terra limpa pelo fogo, ora uma certa porção do solo fértil das vazantes. Planta, então, aqui e ali um pouco de milho e de feijão, alguma batata, uns quantos legumes (PEREIRA, 1948, p. 129).

De acordo com o que foi dito por José Veríssimo da Costa Pereira, a matéria do G1 faz a mesma referência das atividades praticadas pelo caboclo amazônico. São indivíduos que vivem da caça, são coletores, aproveitam do solo fértil para a plantação do milho, mandioca e arroz. Podemos encontrar similaridades entre o texto de José Veríssimo da Costa Pereira e as palavras de Jorge Nunes, um dos moradores do Croa, quando ele diz "Tudo essa terra do Croa dá, só que tem a época de plantar. Eu planto macaxeira, milho, arroz" (ANA, 2015).

As fotografias utilizadas na reportagem também dão o tom desse cotidiano, são recortes de uma realidade da vida diária, bem sabemos que há muito mais do que foi representado pelas fotografias, entretanto elas podem levar o leitor a imaginar como seria a vida das famílias que vivem no Croa, abrindo assim outras representações de um espaço exaustivamente narrado. Além dessas práticas rotineiras como o plantar, o pescar e o andar de canoa, há outra bastante praticada na região. A espiritualidade também faz parte desse contexto. Há na região uma comunidade daimista. Eles começaram a chegar ao Croa a partir dos anos 2000. Segundo a reportagem o "Santo Daime é uma doutrina baseada em ensinamentos cristãos, nascida no Acre, quando o mestre Irineu Serra entrou em contato com a bebida indígena ayahuasca no início do século XX” (ANA, 2015). Nas palavras de Jorge Nunes, o Croa é um lugar ideal para esse ritual porque "Aqui é bom pra fazer estudo na natureza, tem a força da água e dos seres da floresta” (ANA, 2015).

A matéria apresenta também algumas informações sobre a história da comunidade, como a exploração da borracha, a pecuária e por último, a preocupação com a questão ambiental. O místico, o exótico e os saberes do povo da floresta são apresentados com o intuito de criar um ambiente favorável para o turismo.

Seguindo esse mesmo objetivo a próxima reportagem "Fenômeno natural deixa rio com ares de lago paradisíaco no Acre", de autoria de Genival Moura e publicada no G1, em 02 de fevereiro de 2014, mantém a mesma estética do discurso das reportagens anteriores: paraíso, vegetação exuberante, potencial para atrair turistas, política de preservação e o Santo Daime. Nessa reportagem, o Instituto Chico Mendes de Conservação da Biodiversidade (ICMBIO) tenta explicar porque o rio passou a ter a semelhança de um lago. De acordo com a pesquisa,

\footnotetext{
a mudança ocorreu há cerca de 13 anos, quando a água do Juruá, maior rio da região, mudou o curso em consequência do desbarrancamento por causa da correnteza e deixou de represar água para dentro do Croa no período de cheia. Sem a inundação de todos os anos, o rio Croa ganhou caraterísticas diferentes. A pouca correnteza deixou a água mais escura devido à decomposição da floresta, provocando um reflexo com a luz do sol que proporciona uma beleza diferenciada ao lugar. Em vários pontos é possível encontrar as vitórias-régias, uma das maiores e mais belas plantas aquáticas do mundo. Também conhecida como estrela das águas, a planta que faz parte do folclore amazônico, pode atingir até dois metros de diâmetro (MOURA, 2014).
}

Esse fenômeno que deixou as águas do Croa com uma aparência de lago é uma das 
atrações mais famosas do local. Mas o que deixa pairando na matéria é que ela não é a única atração do lugar, suas águas reservam outras surpresas, como a presença de peixes raros (o pirarucu, a aruanã) e também as práticas daimistas. A pesca é uma atividade muito apreciada nesse rio, mas o enfoque dado na reportagem é o Santo Daime. A cultura da ayahuasca é adotada pela maioria das famílias que vivem nessa localidade. Como relata o repórter "a bebida é preparada a partir do cipó de mariri (Banisteriops Caapı) e das folhas de chacrona (Psychotria viridis) plantas encontradas às margens do rio Croa” (MOURA, 2014).

Os adeptos dessa cultura encontram no Croa o lugar ideal para o seu uso. A floresta e o rio são os elementos mais adequados para os rituais. Há força neles. Há sabedoria. Há mistérios. Ao longo do rio há vários centros que praticam esses rituais religiosos. Num deles, o senhor Jorge Nunes da Costa, diz que tem recebido muitos adeptos do chá que vem em busca de paz espiritual. Ele próprio revela que o daime mudou a vida dele ao comentar:

Eu fui alcoólatra durante muito tempo até que encontrei essa santa bebida e achei o caminho. Hoje eu sou curandeiro da floresta, além de benzer as pessoas conheço muito bem e recomendo os remédios da floresta. Esse rio é um paraíso, tem seus encantos, quando a gente escuta o canto de um pássaro ou de uma cigarra tem que ficar ligado, porque alguma coisa eles estão dizendo. Eu aconselho muito os moradores a preservar, em um lugar desses quando se corta uma árvore tem que plantar duas (MOURA, 2014).

Outro morador que montou um centro para a realização desses rituais é Jackson dos Santos Messias. Casado com uma indígena peruana adepta do daime, esse ribeirinho trabalha também como guia turístico. Segundo ele "a cultura religiosa da comunidade, aliada às belezas naturais do rio é uma boa combinação para atrair turistas” (MOURA, 2014).

Esse também é o mesmo pensamento do jornalista Leandro Altheman, para ele o rio Croa é um polo para quem toma o ayahuasca e ainda afirma que sai com frequência da cidade, para passar uns dias no Croa, em busca de paz e de silêncio. Assim como Leandro, muitos visitantes buscam conhecer o Croa e o cotidiano desse povo que resiste as intempéries da floresta amazônica. Eles sentem-se fascinados pelo exotismo do daime, pelos mistérios que giram em torno das representações desse lugar (MOURA, 2014).

A religiosidade e tantas outras características já mencionadas servem na montagem de um espaço, de um local imaginado e perfeito para as atividades turísticas. O Croa se pinta ou é pintado com maravilhosos retalhos de uma narrativa coletiva que se contextualiza numa visão econômica, tendo como objetivo a tessitura de um lugar aprazível, de rara beleza e de natureza bruta.

Assim como a Amazônia, o Croa também está imerso num discurso romanceado, num discurso capaz de atrair a curiosidade, o espanto. A imagem de um lugar abençoado, de uma terra fértil, onde o ar é puro, onde tudo o que o envolve tem uma aura de mistério, de mítico, serve como uma excelente base imagética para a concretização do Éden. Essa busca ganha força em divulgar o que o local tem de mais belo, são fatores que podem ajudar a vender uma imagem de um lugar paradisíaco. O Croa não é uma única coisa, ele é um conjunto de atributos. São essas pequenas partes que dão forma ao todo e que selam essa personalidade percebida, que legitimam esse lugar.

A "personalidade" desse rio já está pronta e acabada. Nesse gênero discursivo, o Croa, as florestas, os animais, as plantas, os costumes, enfim todos os elementos já foram inseridos nela. A alma do rio Croa encontra-se entre o exótico, o mítico, o paraíso, o exuberante, o isolamento, o inferno verde, enfim, aspectos tão contraditórios e tão efêmeros, mas que compõem a trilha sonora desse espetáculo amazônico. Aos olhos do nativo, do residente dos rios, do ribeirinho e do caboclo, a alma do lugar está imbricada em sua identidade individual. Ele pertence ao lugar, se adapta, resiste, persiste.

As quatro narrativas sobre o Croa trabalham com uma dinâmica de representações, 
a Amazônia narrada no período da conquista, com sua flora exuberante e fauna exótica ainda povoa o imaginário dos viajantes. As vozes presentes no discurso de Bakhtin são ouvidas em todos os enunciados presentes sobre esse lugar. Mas essas vozes estão sendo sussurradas em um novo contexto.

Essas reportagens tentam representar a alma do rio Croa. Todos os aspectos utilizados no gênero narrativo apresentam uma busca de se delimitar a personalidade desse lugar. E como seria feito essa construção? Quais fatores seriam usados para determinar a personalidade, a identidade, a alma do Croa? E o que seria essa personalidade do lugar? Segundo Yázigi,

usualmente, a personalidade, ou o conjunto de identidades do lugar, na vida cotidiana, tem sido entendida, como relações sociais, instituições, arquitetura, urbanismo e toda cultura material; costumes e vários outros itens que se repetem em todas as partes, como bem nos dão conta a sociologia, a antropologia e a etnologia (YÁZIGI, 2001, p. 29).

Diante desse conceito de personalidade podemos traçar quais os itens que se repetem em todos os enunciados. São palavras que descrevem exaustivamente a Amazônia e respectivamente o rio Croa. Pode-se supor que essas identidades já estavam presentes nos escritos dos viajantes ibéricos à região, nas narrativas amazônicas de Euclides da Cunha, nas obras de Tocantins, e entre tantos que já descreveram essa região multifacetada chamada Amazônia.

Deve ser por isso que as matérias veiculadas no Acre sobre o rio Croa estejam repletas desses mesmos itens. O Éden é uma boa publicidade para as atividades turísticas. Reforçar a ideia de que a paisagem do Croa é ainda natural, pode ser sem sombra de dúvida uma das maiores jogadas publicitárias.

Tanto o governo do estado como a comunidade sabem o que atrai o visitante. Essa região já povoa há muito tempo a imaginação dos estrangeiros, viajantes e um amplo público externo à ela. Manter a preservação do lugar é uma alternativa para quem quer investir no ecoturismo. As trilhas, os banhos de rio, a pescaria e as grandes árvores são as grandes atrações na região do Croa.

Essa presença da estrutura governamental no Croa reforça a política de sustentabilidade do governo, pois propõe a preservação da floresta com a garantia da sobrevivência da comunidade. Com base nisso, as potencialidades turísticas da região tem obrigado o governo a investir numa estrutura que garanta a eficácia do turismo contemplativo. A chegada da luz ao Croa é uma prova desses investimentos e também uma maneira de se oferecer um pouco de conforto aos visitantes.

Ainda com a ajuda do governo, um projeto arquitetônico foi elaborado. Serão construídas algumas cabanas, a proposta é que se mantenham as mesmas especificidades das casas dos ribeirinhos, pois a preocupação é não intervir muito na "paisagem natural" do Croa. Além das cabanas, seriam construídas algumas lojas para os artesanatos locais e também um restaurante. Entretanto, até o projeto sair do papel, os interessados em conhecer/visitar o Croa podem se hospedar na pousada ou podem desfrutar da hospitalidade do caboclo gentil, pois há alguns moradores que oferecem quartos para alugar.

Todos os elementos abordados na escrita dessas reportagens já serviram e ainda servem como fios para a construção de um cenário idílico de uma determinada paisagem amazônica. A visão dos moradores do local revela a construção de uma mesma ideologia, numa tentativa de dar alma ao lugar. Ou como diz Yázigi, “o homem apaixonado pelo meio cria a alma do lugar” (YÁZIGI, 2001, p. 45).

O morador do Croa construiu/descontruiu esse lugar. Ele se adaptou ao meio, mas para isso teve que intervir. A paisagem apresentada não é a natural, ela foi humanizada. Não é mais a natureza bruta, e sim a interação homem/natureza. Nesse processo intervencionista o homem se coloca como parte do cenário, absorvendo, aprendendo, se adaptando. O seus hábitos, seus movimentos e também seus pensamentos estão regulados por uma sucessão de imagens que lhe apresentam o mundo exterior. O sentimento de pertença surge nesse momento de interação e está impregnado em sua pele, em sua 
identidade. Apesar da geografia da Amazônia ser predominantemente humanizada, ela ainda é no discurso um elemento secundário. O ribeirinho, o caboclo, o nordestino, ou tantos outros tipos narrados, não se sentem como autores de sua história. Para eles é a natureza que compõem todos os atos dessa peça.

Embora as visões do morador e do turista mantenham alguns elos em comum, suas percepções desse espaço são totalmente diferentes. Os moradores pertencem ao lugar. Já os visitantes que participaram de algumas dessas narrativas possuem um olhar diferenciado, pois esse olhar está direcionado ou focado na diferença. Tudo o que se apresenta/revela descortina um mundo novo. Ele fica admirado com o modo de vida do caboclo, seu modo de falar e de perceber o mundo. O turista quer ver novidades. O desconhecido chama a sua atenção. Toda a paisagem criada pelas narrativas constrói um mundo que embora não seja real, não deixa de ser interessante.

A personalidade do Croa criada pelos moradores do lugar causa espanto aos olhos do visitante. É a fauna, a flora, as casas nas margens do rio, a canoa que singra as águas. Mas ela vai muito além do que essas imagens podem supor. O fantasioso também faz parte dessa personalidade. É a força da floresta, são as lendas, toda a fantasia que cerca essa região de uma infinidade de seres que vão além de toda e qualquer imaginação. Nesse sentido, Yázigi define bem esse processo quando comenta,

sou levado a reconhecer que a personalidade do lugar se apoia num amplo conjunto de identidades - história; costumes; arquitetura; urbanismo com suas ruas, barrancos e bocas malditas; detalhes e adornos; tipos humanos e suas relações com o meio e a região; pertença; formas linguísticas; mitos; fantasmas e aparições da santa; esconderijos; sons específicos; astral; segredos e todos diferenciais próprios do meio ambiente (relevo, hidrografia, fauna, flora, clima luminosidade, etc) (YÁZIGI, 2001, p. 45).

A "alma" do rio Croa revelada pelas reportagens assume um caráter publicitário, entretanto, muitos moradores do Croa já criaram e assimilaram esses traços identitários e estão propagando-os dialogicamente. São vozes sussurrantes do cotidiano que ecoam pela floresta, com uma sonoridade tão pungente que é impossível não ouvir o canto que diz: Croa, o paraíso é aqui.

\title{
THE CROA RIVER: THE RESULT OF MANY VOICES. A PLACE NARRATED FROM THE POINT OF VIEW OF ECOTOURISM
}

\begin{abstract}
This article seeks to reflect on the news circulating in the State of Acre, originated from websites that narrate/represent the Croa River as a paradise, enchanted place, inhabited by pleasant people and endowed with a great potential for tourism. By analysing this discourse through the prism of Bakhtin's thought, it is possible to understand how these narratives were created, drawing on small details of a given reality, result of a discursive memory, and how new elements were inserted dialogically through a tourism-oriented perspective. The community living along this river, situated in the Juruá Valley, in the Acrean Amazon, dialogically inserts new meanings, new interpretation of/on the place, indicating that the Edenic representation of traditional narratives is vivid and still influences present imagery. It is an old discourse, that produces a new text about the Croa River.
\end{abstract}

\section{KEYWORDS}

Croa River. Paradise. Discourse.Tourism. Amazonia.

\section{REFERÊNCIAS}

ANA - Agencia de Notícias do Acre. Água escura que espelha a beleza do Acre. Disponível em http://goo.gl/ RlCt7O. Acesso em 02/01/2015.

BAKHTIN, M. Os gêneros do discurso. In Bakhtin, M. Estética da criação verbal. São Paulo: Martins Fontes, 2003. pp. 261-306.

CAMPOS, T. No coração do Croa. Disponível em http://goo.gl/L5Eqbz. Acesso em 02/01/2015. 
CUNHA, E. À margem da História. São Paulo: Ed. Martin Claret, 2006.

JURUÁ ONLINE. Programa luz para todos chega ao Rio Croa. Disponível em http://goo.gl/vcsb9H. Acesso em 02/01/2015.

MOURA, G. Fenômeno natural deixa rio com ares de lago paradisíaco no Acre. Disponível em http://goo.gl/ jg6wtu. Acesso em 02/01/2015.

PEREIRA, J. V. C. Caboclo amazônico. In Revista Brasileira de Geografia: Sumário do Número de Outubro-Dezembro de 1948, Rio Grande do Sul, Ano X, n. 4, 1948, pp.129-131.

TOCANTINS, L. O rio comanda a vida: uma interpretação da Amazônia. 9. ed., Manaus: Valer/Edições Governo do Estado do Amazonas, 2000.

YAZIGI, E. A. A alma do lugar: turismo, planejamento. São Paulo: Contexto, 2001.

UGARTE, A. S. Sertões de bárbaros: o mundo natural e as sociedades indígenas na Amazônia na visão dos cronistas ibéricos - séculos XVI/XVII. Manaus: Valer, 2009.

Data de recebimento: 20/01/2016

Data de aceite: $15 / 03 / 2016$ 